\title{
New Age Spirituality, Abiku and Hunger in The Famished Road
}

\section{Douglas McCabe}

\section{(2) OpenEdition \\ 12 Journals}

Electronic version

URL: https://journals.openedition.org/ces/5324

DOI: $10.4000 /$ ces.5324

ISSN: 2534-6695

Publisher

SEPC (Société d'études des pays du Commonwealth)

\section{Printed version}

Date of publication: 1 April 2013

Number of pages: 21-31

ISSN: 2270-0633

\section{Electronic reference}

Douglas McCabe, "New Age Spirituality, Abiku and Hunger in The Famished Road", Commonwealth Essays and Studies [Online], 35.2 | 2013, Online since 17 April 2021, connection on 23 July 2021. URL: http://journals.openedition.org/ces/5324 ; DOI: https://doi.org/10.4000/ces.5324

\section{(c) (†) $\odot$}

Commonwealth Essays and Studies is licensed under a Licence Creative Commons Attribution - Pas d'Utilisation Commerciale - Pas de Modification 4.0 International. 


\section{New Age Spirituality, Abiku and Hunger in The Famished Road}

This article shows that Okri's representation of abiku is profoundly shaped by the discursive history it inhabits in the present and inherits from the past. It demonstrates how

Okri's portrayal of a chronically hungry abiku boy is both indebted to and in tension with pre-colonial and colonial abiku discourses and the inter-religious contests they embody, and suggests that Okri's abiku epic is an object lesson in the pursuit of an African postcolonial spirituality.

Commentators on Ben Okri's The Famished Road rightly point out that the novel's title is an allusion to Soyinka's play The Road and poem "Death in the Dawn," both of which contain the phrase, "May you never walk when the road waits, famished" (Adu-Gyamfi; Quayson 121-2). This line is Soyinka's translation of the common Yoruba prayer Ká má rin l'ójó t'ebi npònà, "May one not walk on the day that the road [òna] is hungry [ebi]" - a prayer usually uttered when reflecting upon a journey-related accident (as in Soyinka's poem) or when someone is embarking on a journey. "Road" is the standard Nigerian English translation for the Yoruba ònà, which means not only the wide concrete streets and highways that native English-speaking Westerners associate with the word "road," but also (and pre-eminently) the dirt footpaths and bush-tracks that still crisscross southern Nigeria and form the basis of much local travel. As such, the best Western English translation of òna is the more general and all-encompassing "way" or "path" or "track" - and Soyinka no doubt knows this. Similarly, the standard Nigerian English translation of ebi is "hunger" or "hungry," a translation that correctly captures the normal kind of "I-really-want-to-eat" hunger implied by $e b i{ }^{1}$ Soyinka's "famished" is an unusual, hyperbolic translation of ebi, denoting as "famished" does an extreme, ravenous hunger - the hunger of someone literally starving to death. One could argue, therefore, that Soyinka's use of "famished" and "road" to translate the Yoruba prayer is deliberately catachrestic, a mis-translation intended to capture the new, hyperbolic hazards engendered by exogenous, "colonial" forms of locomotion (the concrete road and the metal automobile). Okri's use of Soyinka's mis-translation is surely meant to encapsulate a similar, ambiguous awe at the effects of colonial modernization: throughout The Famished Road, we hear of articulated lorries plunging into houses (9), of burnt-out vans (155), of cars terrorizing neighborhoods (379), of mega-highway projects that destroy the jungle and "eat" human beings (288). In addition, Okri's "famished," attached as it is to things African and deployed (as his novel pre-eminently is) in a Western discursive space, conjures up the pictures of mass famine, skeletal emaciation, and severe malnutrition that dominate late twentieth-century Western conceptions of African life. The human hunger we find throughout the novel plays on this popular Western conception of starving Africa prevalent at the time of the novel's composition, working

1. Interestingly, Bishop Samuel Crowther, writing in the early nineteenth century, tells us that ebi means both "hunger" and "journey" (79). Perhaps the homonym originated from a metaphor: when one takes a journey, it is as if the path one takes is a mouth and throat leading to a stomach - one's destination. This pre-colonial simultaneity of "hunger" and "journey" in ebi enriches our understanding of the Yoruba proverb and of Okri's use of both tropes in his novel. 
to show that, beneath the propaganda of international charities (the so-called "hunger industry") and despite material scarcities, the poor of Africa still lead lives worth living, full of richness, magic, dignity, and triumph.

But there is more to Okri's use of "famished" and "road" than its allusion to Soyinka's texts, its courteous nod to indigenous traditions, its anti-bourgeois affirmation of the working poor, and its critique of colonial modernization and the contemporary hunger industry. For discursive representations of hungry and mobile abiku have a long and politically loaded history - a history that Okri's text inherits, is influenced by, and pushes against. For example, the idea that abiku children are "famished" was largely invented by a turn-of-the-century colonial religious anthropologist, A. B. Ellis, in whose writings it embodied a Social Darwinist view of religion ("higher" races have "higher" religions; one's religious belief indicates one's position on the evolutionary ladder). Okri's own "famished" abiku is, I argue below, very similar in form to that of its colonial inventor, but the politics of his representation is gripped by spiritual anxieties and values quite different from (though, as it turns out, not entirely unrelated to) those animating the colonial text. The same is true of representations of perambulatory abiku, which have an even longer and more varied history, stretching back into the deep recesses of the oral imagination. In Yorubaland during the nineteenth century, for instance, the oral representation of wandering abiku was embroiled in a local contest between competing spiritualities - the "possession" cult of Sàngó, the "sacrificial" cult of Ògun, and the "divinatory" cult of Ifá. Azaro, the wandering abiku of Okri's epic, is in many ways the spitting image of his oral ancestors, even if the spiritual politics of Okri's mazy abiku is, once again, in tension with those earlier texts. In the end, we find that the New Age spirituality predominantly shaping Okri's representation of abiku is at once sharpened and destabilized by the tacit background presence of Okri's oral and colonial abiku precursors. ${ }^{2}$

The motifs of food and hunger, eating and not eating, are, like the motifs of roads discussed above, central to The Famished Road and its representation of abiku. Over the course of the novel's 574 pages, we hear innumerable times that the abiku boy Azaro is "hungry"; and we have the pleasure of watching him consume food with equal frequency. As I will argue below, there is a sense in which this motif of ravenous abiku belongs to Okri's New Age allegory. But the discursive origin of this motif - early colonial religious anthropology on the Yoruba - serves to complicate the spiritual politics of Okri's text, coloring our understanding of the novel in surprising ways.

Images of voracious eating are, of course, part of almost every indigenous religious tradition in southern Nigeria. The gods are said to be "hungry" for sacrifice. The Yoruba say that Stomach must be the hungriest god, because he is always being fed (Ellis 122). Witches are said to "eat" human babies and to "cook" the spiritual part of their victim before "eating" it. Indeed, one cause of abiku, according to Ifá babaláwo, is witchcraft; witches keep eating the mothers' children (Aworeni; Ifayinka). ${ }^{3}$ Azaro's dream-images of Madame Koto growing fat on people's souls tap directly into this preand post-colonial indigenous discourse about child-eating witches - a discourse which, as Rosalind Shaw argues, was inspired by the pervasive kidnapping of children during the transatlantic slave trade (Shaw 856-76). If so, and if pre-colonial representations

2. For a lengthy discussion of New Age spirituality in The Famished Road, see McCabe "Higher Realities," 1-21.

3. For more on Yoruba witches, see Morton-Williams and Prince. 
of abiku were similarly inspired, then there is a direct, if tacit, connection between pre-colonial religious images of rapacious hunger and pre-colonial representations of $a b i k u$. It is therefore not surprising to find a hungry witch and a chronically kidnapped abiku (Madame Koto and Azaro) jointly articulated in The Famished Road, a novel which is suffused with trappings of pre-colonial Nigerian spiritual discourse.

But hunger and eating have an even closer and clearer historical relationship to abiku than is implied by the general prevalence throughout indigenous Nigerian religions of food and ingestion metaphors. This is because the very first account of abiku - Crowther's brief entry in the 1852 printing of his $A$ Vocabulary of the Yoruba Language explicitly links abiku with hunger, a link seized upon and modified by the first extended study of Yoruba religion - Colonel Alfred Burdon Ellis's 1894 The Yoruba-Speaking Peoples of the Slave Coast of West Africa - in a way that reflected Ellis's historically contingent concerns as a colonial religious anthropologist. Crowther's entry runs thus:

$\mathrm{ABI}-\mathrm{KU}, \mathrm{s}$. the spirit of children who die in infancy. Infants, or children who die under ten or twelve years old, are called Abiku, and are never buried in the town, being sometimes even thrown away in the bush, as a punishment. They are supposed to have had evil spirits for their companions, who have enticed them away. The evil spirits are supposed to punish the children with cruel whippings, if they do not give them the things which they require of them. If a child grows thin, his companion spirits are affirmed to be taking away his food from him; hence, to appease these spirits, sacrifices are resorted to; and to frighten the spirits away, charms are hung about the child, and iron rings are put on his feet, the jingling of which is supposed to drive the spirit [sic] far away. (4, my emphasis)

Notice that Crowther makes no mention of repeated births and deaths; the idea of an abiku "cycle" only coalesces in the mid twentieth century, just in time to feed (and partly as a result of) modern Nigerian writers' and literary critics' eager search for vernacular metaphors. But the central point to be made here is simply that Crowther defines abiku in part by reference to emaciation and food-stealing.

This small feature of Crowther's definition is taken up and amplified by Ellis in his seminal work on Yoruba religion:

The general idea seems to be that the uninhabited tracts of country abound with numbers of evil spirits or demons, who suffer from hunger, thirst, and cold, since nobody offers sacrifice to them and they have no temples, and who are constantly endeavouring to improve their condition by entering the bodies of new-born babes. Only one Abiku can enter and dwell in the body of the same child, and, as there is great competition amongst the Abikus for such a position, an Abiku is only suffered by his companions to enter peaceably, and, in fact, to be recognised as having vested rights in a child, on condition of his promising them a share of the comforts he is about to obtain.

When an Abiku has entered a child he takes for his own use, and for the use of his companions, the greater part of the food that the child eats, who in consequence begins to pine away and become emaciated. [...] It is the incessant demands that are made by the hungry Abikus outside, and which the indwelling Abiku has to satisfy, that destroy the child [...]. [The child] is being starved because the Abiku is stealing all its nourishment. To get rid of the indwelling Abiku, and its companions outside, the anxious mother offers a sacrifice of food; and while the Abikus are supposed to be devouring the spiritual part of the food, and to have their attention diverted, she attaches iron rings and small bells to the ankles of the child, and hangs iron chains round his neck. (112-3)

Here, as in Crowther's text, abiku births and deaths are pictured as the effect of hunger and ravenous eating: starvation and material scarcity ("hunger, thirst, and cold") drive the abiku into a mother's womb; the ravenous eating of the abiku's companions cause 
its death by starvation. But Ellis's account is decidedly more colorful than Crowther's: where Crowther had simply "evil companions," Ellis has a more complex and dramatic story, presenting abiku as a band of homeless ragamuffins quarrelling over which of them will "improve their condition" by entering a child and "stealing all its nourishment."

We may never know how far Ellis's colorful departure from Crowther's hungry abiku is due to his allowing himself some imaginative license ("The general idea seems to be" indicates this) and how far it is due to his perusal of Crowther being supplemented by tutelage from native informants. Certainly, the anthropological validity of Ellis's account of famished abiku can be called into question on several grounds; preeminently, on the grounds that Ifá babaláwo from the Ibadan, Ife, and Oyo areas of Yorubaland today do not volunteer the particularly strong link between abiku and hunger that characterizes Ellis's account. But Ellis could have obtained his information from the Owo-Yoruba sub-group area, an area where, as one Nigerian scholar puts it (echoing Crowther), "Depreciation in the astronomical growth of a child is [held to be] another symptom of the abiku phenomenon. This is a result of the fact that the food meant for the child is not only consumed by him but by other members [of his] egbe"' (Babalola 63). The Owo-Yoruba area, perhaps not coincidentally, borders on Urhoboland, the provenance of Okri's parents. If the Urhobo share a pre-colonial account of abiku similar to the Owo-Yoruba, then this might explain why Okri associates abiku with hunger and eating. Even if this were true, however, it would still be worth assessing how Okri's abiku representation differs from or overlaps with Ellis's account, if only because the latter's talk of "hungry" abiku who "starve" children to death was taken up and circulated by early twentieth-century colonial ethnographers and quickly became the de facto "truth" of abiku in Western colonial discourse in the first half of the twentieth-century, paraphrased virtually verbatim in the important accounts of Yoruba religion offered by District Officer Percy Amaury Talbot and the Scottish Africanist Reverend S. S. Farrow in the 1920s and by the Yoruba-born scholar J. Olumide Lucas in the 1940s.

The politics of Ellis's representation of famished abiku (and, by extension, that of other colonialist commentators who reproduce his discourse) is complex: his picture of abik $u$ is shaped by at least two views about religion competing for hegemony in the Victorian society to which he belonged. The first view was the Social Darwinist position that more "evolved" (fitter) races and classes produce more "evolved" (fitter) religions and other cultural institutions. ${ }^{4}$ The stated purpose of Ellis's anthropological volumes on peoples from the southern coast of West Africa (of which The Yoruba-Speaking Peoples constitutes the third and final volume) is explicitly evolutionist.

For example, he traces the "evolution" in conceptions of divinity from animism (in which the gods are local rocks and rivers, as they are among the Tshi) to polytheism (in which the gods are "national and general," shared by "a whole people, as among the Yorubas") (292). Similarly, he traces the "evolution" of religious morality from the "lower" Tshi tribe (for whom there is no connection between religious worship and moral behavior) to the "higher" Yoruba tribe for whom there is now an inkling that good works and spiritual life are somehow related (292-4).

4. On Social Darwinism in Victorian England, see Greta Jones and Nancy Paxton. On Social Darwinism as it related to issues of religion, race, and colonialism during the period, see especially Bannister 180-200; Hammer 255-60; G. Jones 140-59; Numbers and Stenhouse 123-43. 
But there is another, second influence shaping Ellis's representation of hungry abiku which sits uneasily with the influence of Victorian Social Darwinism. This is the influence of what might be called progressive materialism, the view, handed down to the Victorians by such Enlightenment figures as Adam Ferguson and incorporated into the economic theories of Marx and Engels, that social (ideational) progress is brought about by progressing through stages of greater and greater economic (material) sophistication. ${ }^{5}$ Like many Africanists of his own and later generations, Ellis is keen to point out that Yoruba religion bears "striking resemblance" to the religion of the ancient Greeks (295).

He offers a progressive materialist rather than an evolutionist view of religion: different levels of technological sophistication, economic complexity, and society size ("civilization") necessarily generate different desires and anxieties, which in turn necessitate different types of religious system and spiritual experience. The material base, Ellis appears to say, determines the ideational superstructure. The religions of the Yoruba and ancient Greeks are therefore fundamentally the same because their technology, economies, and political systems are the same. This materialist view, strictly speaking, contradicts the racist evolutionism of the Social Darwinists. For, as in all materialist views, there is a salutary element of demystification and leveling in the sense that all religious systems become significantly equal when they are viewed, not as true descriptions of divinity, but as useful coping mechanisms for historically contingent needs and desires. Moreover, the racist biology implied by some forms of social evolutionism (the "lower races" have innately "lower" intelligence, producing innately "lower" forms of spirituality) is contradicted by the materialist idea that it is one's economic stage ("plane of civilization") - not one's race - which determines one's spirituality. Read against the backdrop of this progressive materialist side of his argument, Ellis's portrayal of Yoruba abiku as hungry, homeless pseudo-humans that are a "corruption" of an "earlier" Tshi/Ewe belief in kra appears to confirm and endorse the progressive materialist view of human religions (less sophisticated economies have vaguer, less anthropomorphic divinities) rather than the Social Darwinist view with which it historically competed.

Ellis's account of hungry abiku, then, is shaped by and embodies a conflict between two views of spirituality that competed for ascendancy in Britain at the end of the nineteenth century. Both ideologies - the Social Darwinism of Herbert Spencer identifying "more evolved" races with "more evolved" religions; the progressive materialism identifying sophisticated economies with social progress - find themselves jointly articulated in Ellis's interpretation of Yoruba spirituality, even if one (the evolutionary sociology) appears to be his guiding star. In short, how Ellis represents abiku in his seminal work on Yoruba religion is deeply imprinted by his own fraught history as an inheritor of multiple nineteenth-century European views on the nature and causes of spirituality.

Okri's representation of hungry abiku in The Famished Road therefore inherits a very considerable discursive history, a history embroiled, particularly when it comes to Ellis's text, in different views about spirituality and the different values and concerns underpinning those views. How does our knowledge of this history illuminate Okri's representation of Azaro's famished eating?

5. On the Scottish Enlightenment and the progressive "stadial" view of history, see Beiser and Nisbet. 
The first mention of hunger (after the title) occurs in the novel's first paragraph, where we are told that "because the road was once a river, it was always hungry" (3). In Okri's New Age allegory, this means that our true spiritual selves - pure, flowing, and intricately connected with the natural world, like a river - have been paved over by our false worldly selves - sclerotic and fixed and destructive to their surroundings, like a road. For this reason, our incarnated selves ("road") are always "hungry," longing to be the crystalline "river" of pure spirit that we once were and can become again. Because we are incarnated, moreover, we are also "always hungry" in the sense of suffering material scarcities, losses, and injustices on the road toward death. As with other key motifs in Okri's spiritual allegory, then, hunger is double-edged: it signifies (a) material scarcity (physical hunger) in the world, which is ultimately caused by (b) everyone's separation from and longing (metaphysical hunger) for their true spiritual selves.

The abiku boy Azaro's chronic hunger and ravenous eating is surely part of Okri's New Age paradigm: they point not only to the material scarcity Azaro suffers but also to his spiritual alienation, his being not-at-home in the human world of unactualized Selves. There is a touch of light-hearted self-travesty on Okri's part here because Azaro's hunger and eating are so chronic (indeed, constant) that they begin to look just a little ridiculous and over-inflated - an absurd hyperbole of hunger and desperate feeding rather than their "realistic" representation. One such (purportedly) realistic representation of African hunger and feeding is, of course, Western news media coverage of late-twentieth-century periods of famine on the African continent - coverage which, as already pointed out, has helped define Africa for the West. Okri's travesty of Azaro's hunger is a caricature of such obsession with and reification of Africa as the continent of famine, just as it is also a self-reflexive lampoon of The Famished Road's intensely earnest and deeply sincere New Age allegiance to the overcoming of material oppression through spiritual self-realization. Here is an example of how Okri's text, importantly shaped by the New Age, also detaches us from its ideology, helping us see it from the outside.

The New Age message encrypted in Azaro's chronic hunger is also destabilized by the hunger's inevitable resonance with Ellis's discourse of famished abiku. For to the extent Okri's representation of Azaro harmonizes with and confirms Ellis's discourse, it is also contaminated by it, unwittingly conjuring the colonialist politics of the latter, its evolutionary view of spirituality flickering between social Darwinism (abiku as ravenous animal: a brutish religious imagining of the lower races) and historical materialism (abiku as ravenous animal: the religious effect of a low-tech economic base). By representing the abiku Azaro as always hungry, in other words, Okri's text is guilty by association, unwittingly reproducing the colonialist view of African spirituality as "uncivilized" or "lower" which, for most of the twentieth century, has been encoded in the idea of famished abiku. This corroboration is clearly in tension with and sullies the egalitarian New Ageism (all religions are equal; every human being has an "inner Self" of "cosmic love") that Azaro's chronic hunger also invokes.

Like the formal similarity between Okri's and Ellis's texts, the points of formal dissonance between them are a cue to their different spiritual politics. Whereas Ellis's abiku are ravenous brutes who kill one of their own by stealing and devouring its nourishment, the hunger and eating of Okri's famished abiku are eminently human. Moreover, whereas Ellis's incarnated abiku always eats in the spiritual company of his fellow non- 
incarnated abiku, Azaro is typically depicted as eating alone or in human company. To pick a random example from Okri's text:

While running through the forest paths I [Azaro] stepped on an enamel plate of sacrifices to the road. The plate was rich with the offerings of fried yams, fish, stewed snails, palm oil, rice and kola-nuts. Shell fragments and little pins stuck in the soles of my feet. I started to bleed. I was so hungry that I ate what I could of the offerings to the road and afterwards my stomach swelled and visions of road spirits, hungry and annoyed, weaved in my brain. (114)

At this point, Azaro has been roaming the streets overnight after having escaped from the albino twins, his would-be kidnappers; his desperate feeding on sacrificial food left for the road-god is, in this context, not the indiscriminate ingestion of an insatiable beast but the completely human decision to survive. And although, like Ellis's incarnated abiku, he appears to be afflicted by other hungry spirits, Okri's text - in a move typical of the novel's ubiquitous humor - indicates that these road spirits are not metaphysical predators but just the metaphysical pyrotechnics of something very human: food poisoning, as indicated by his swollen stomach. Here, Okri's representation of a very hungry, yet very human, abiku is at odds with Ellis's text, tacitly contesting the evolutionist view of African spirituality implicit in the latter (abiku as hungry animals reflects "inferior" religious development) and seeding a New Age view of African spirituality in its stead (abiku as hungry humans reflects how ordinary physical suffering has metaphysical effects and vice versa). In short, Okri's depiction of Azaro's chronic eating and emaciation is both shaped by and in tension with the colonialist religious anthropology of famished abiku that he inherits.

Although the main plank in Okri's representation of hungry abiku is the volume and frequency of Azaro's feedings and stomach-rumblings, this plank is supported by innumerable other elaborations throughout The Famished Road on the same theme. One of the most obvious is Azaro's name, which, in its long form as Lazaro, clearly alludes to the biblical story of Lazarus, as the text itself is at pains to alert us ("many were uneasy with the connection between Lazaro and Lazarus" [8]). Of course, there is a sense in which this allusion is simply meant to assimilate Christian mythology with indigenous African mythology, an assimilationist practice mastered by Soyinka (see, e.g., Myth 1-20) under the influence of mid-twentieth-century "archetypal" anthropologists (e.g., Jung and Kerenji - cited in Soyinka, Myth 10). But there is something else behind the politics of Okri's biblical allusion that is not wholly reducible to a humanist politics of religious assimilation - a something else complexly and problematically entwined with Ellis's representation of hungry abiku.

Very much like the account of the death and raising of Lazarus (John 11: 1-44 in The King James Version), Azaro wakes up "in a coffin" several days after his "parents had given [him] up for dead" (8). Such miraculous awakenings from the dead are a staple of indigenous abiku representations, both in pre-colonial Ifá discourse and in contemporary popular Nigerian cinema, where such abiku resurrections come across as thrillingly evil and sensationally terrifying (e.g., Kokumo). However, it is not Okri's allusion to the Lazarus in the gospel of John that concerns us here, but rather his allusion to the very different parable of Lazarus and the Rich Man found in the gospel of Luke:

There was a certain rich man, which was clothed in purple and fine linen, and fared sumptuously every day: and there was a certain beggar named Lazarus, which was laid 
at his gate, full of sores, and desiring to be fed with the crumbs which fell from the rich man's table: moreover the dogs came and licked his sores. (Luke 16: 19-21 [KJV])

Here, Azaro's abik $u$ hunger is aligned with and re-envisioned as the biblical hunger of Lazarus, whose material suffering is converted at death to the comforts of heaven while the sumptuous faring of the rich man is converted at death to the torments of hell, which include food and water deprivation (Luke 16: 24). Thus, by choosing the name he does for Azaro, Okri, on the one hand, dislodges the idea of famished abiku from its roots in colonialist evolutionism, picturing it instead in Christian terms - that is, in terms of the putatively "higher" form of spirituality with which Ellis's famished abiku was supposed to contrast. By doing so, Okri not only contests Ellis's politics, but also reiterates his New Age idea that spiritual riches (Lazarus's rise to heaven) can pour forth from even the most materially scarce of situations (Lazarus's beggary) - an idea that becomes the central theme of Okri's third abiku novel, Infinite Riches. On the other hand, however, there is a sense in which Okri also capitulates to Ellis's colonialist position on human religion. For Azaro's abiku hunger is saved from its inherited associations with a "lower" spirituality here because it is re-associated with the "higher," Christian one. Okri's revision of hungry abiku in New Age terms is contaminated by its reliance upon the very colonialist representation of famished abiku it otherwise works to contest.

Azaro's name is not the only allusion to the biblical Lazarus in The Famished Road which affects the relationship between Okri's representation of hungry abiku and the colonialist representation he inherits. Consider the following episode of hunger and eating, one of many where Azaro spends the afternoon and evening at Madame Koto's bar: "When I went to Madame Koto's bar after school, the place was empty. I was hungry. Sitting near the earthenware pot, I kept telling myself that I didn't have a stomach" (83).

To forget his hunger, Azaro begins to wander the bush-paths and when he returns to the bar is confronted by a grotesque-looking unkempt crazed beggar: "He had on only a pair of sad-looking underpants. [...] He had a big sore on his back and a small one on his ear. [...] His mouth looked like a festering wound" (84). The madman begins chasing Azaro, so Azaro picks up a dead lizard and throws it in defense. The madman begins "to eat the lizard [...] with a weird serenity" (84). Eventually, Madame Koto comes to the rescue, beating the beggar away with her broom and serving Azaro a delectable chicken-head soup to calm his nerves and assuage his hunger: "I cracked the chicken's head with my teeth. I broke its beak. I swallowed down its red comb. I scraped off the thin layer of flesh on its crown" (86).

This episode is intriguing for many reasons: for example, the simultaneously comical and repellent description of grotesque bodies and their orifices - the man's festering mouth, Azaro's toothy mastication - is typical of the novel, functioning in Okri's New Age allegory as the visible sign of the Self's disfigurement by society and the ego. Moreover, when Azaro tells himself he "has no stomach" to cool his "hunger," he clearly echoes the contemporary Western inheritors of Ellis's colonialist discourse, the neo-gothic hypertexts in which abiku are described as "always hungry" because they "have no stomachs." But the main point to be made here is that the crazed beggar is a kind of Lazarus: covered in sores, he comes to the rich person's gate (i.e., Madame Koto's bar door) to eat the crumbs off her table. Here, Azaro's abiku hunger is linked again to Christian discourse with effects similar to those just discussed. Simultaneously, 
however, the beggar is clearly meant to represent Azaro's "unbearable" hunger in its externalized form: when Azaro is hungry, the madman chases him like a predator; when Azaro is eating, the deranged man is nowhere to be seen; and the boy's greasy mastication of the chicken-head is clearly meant to parallel the beggar's chomping of the lizard. This demon of externalized hunger chasing after an abiku recalls Ellis's description of non-incarnated abiku, "who suffer from hunger, thirst, and cold" and who therefore "make incessant demands" on their incarnated companion until the human child housing that companion dies (112). Just as these parasitic, feral abiku can only be "driven away" by a child's mother (Ellis 113), so the pitiable, brutish madman is driven out "as if he were a cow or a goat" by the semi-maternal figure of Madame Koto (84 and 85 respectively). In short, Azaro's hunger is aligned with the biblical Lazarus's hunger in a way that not only embodies Okri's New Age concerns but also, and contradictorily, reproduces the politics of Ellis's representation of famished abiku. New Age spirituality is shadowed, the text seems to say, by the very anti-egalitarian impulses it seeks to distance itself from.

Though the novel asks us to link the abiku boy Azaro's name (and his hunger) to the biblical Lazarus, there is also a sense in which it asks us to separate them. For the story of Azaro's naming contains an explicit attempt to stifle any connection between the boy and the biblical beggar:

When I woke up I found myself in a coffin. My parents had given me up for dead. They had commenced the burial proceedings when they heard my fierce weeping. Because of my miraculous recovery [after appearing to be dead for two weeks] they named me a second time and threw a party which they couldn't afford. They named me Lazaro. But as I became the subject of much jest, and as many were uneasy with the connection between Lazaro and Lazarus, Mum shortened my name to Azaro. (8)

Mum clearly did not intend the name "Lazaro" to conjure the name "Lazarus" - and is so distraught that her son might grow up to become, like Lazarus, a sore-covered beggar or a Christian that the name is shortened to "Azaro." But why did the neighbors "jest" at the new name? Perhaps the intended meaning of "Lazaro" was "Lays around" (pidginized to "Laz' aro"), commemoratively and humorously encapsulating the boy's marathon somnolence. Or perhaps the intended meaning of the name was "Stand defiantly" (the Yoruba Làsàà-rô), indicating how Azaro stayed alive against the odds - the "jest" among neighbors being that the boy, rather than standing for two weeks, was lying down. But it may be that the name was intended to mean "Licks yam pottage" (the Yoruba Lá-àsáró), celebrating something distinctive and characteristic about the boy: his fondness for food and eating. Such a name might have become a jest among the neighbors because Mum and Dad have very little food to offer Azaro - so Mum changes the name to "Yam pottage" (Ásáró) as a way of saying that their child holds the promise of, or is as sweet to his parents as, yam pottage.

This last interpretation of the name "Azaro," however, suggests not only that the abiku boy holds out the future promise of material well-being for his parents, but also that he is food as well. And this is, indeed, what we often find in the novel: Azaro twice falls into a hole or ditch in the road, finding himself in the road's "stomach" $(8 ; 16)$; crazed beggars twice chase him thinking he is food (17; 84); he is abducted several times - "eaten" in a metaphorical sense; and when Dad begins training for his big boxing match, ravenously eating all the food in the house, Azaro grows emaciated, consumed 
in the course of Dad's idealistic pursuit of justice (366-7). Thus, Azaro lives up to the interpretation of his name as "Yam pottage": not only does he eat food himself, but he is in some sense the food of others. In such a way, Okri's abiku boy is once more aligned with Ellis's famished abiku, who in effect "eat" their incarnated abiku companion by stealing its food. There is a twist here, however, for it is not some feral spirits who devour Azaro, as one might expect if Okri's text were sticking to the representational template of its colonial predecessor. Rather, Azaro is eaten by greedy, criminal, overzealous, or otherwise Self-alienated human beings (e.g., beggars, kidnappers, Dad) and by the negative accoutrements of modernity surrounding them (e.g., ghettos, potholeridden highways). In short, interpreting Azaro's name as "Yam pottage" re-invokes the colonialist representation of famished abik $u$ and the spiritual evolutionism underpinning it, but also, and somewhat contradictorily, serves to invoke a feature of Okri's New Age message (the human spirit is imperilled by the human ego and its products). Here, as elsewhere in Okri's representation of hungry abiku, the New Age is uncomfortably aligned with Ellis's colonialist discourse.

In this article I have tried to show that Okri's representation of abiku is profoundly shaped by the discursive history it inhabits in the present and inherits from the past. Okri's portrayal of abiku heaven and of a chronically hungry and perambulatory abiku boy is both indebted to and in tension with pre-colonial and colonial abik $u$ discourses and the inter-religious contests they embody, just as its meaning is also delimited and ramified by the formal similarities and differences between it and its spiritually-concerned contemporaries in Nigerian popular culture. In such a way, The Famished Road engages in a complex contest between different ideas of spirituality, different forms of religious worship, different accounts of the right "road to heaven." Okri's text manifestly takes the side of the New Age in this contest - though, as we have seen, the text's allegiance to the values of Self-actualization, religious egalitarianism, and de-traditionalization are clouded and placed in question by their propinquity to other spiritual values.

In this sense, Okri's abiku epic is an object lesson in the pursuit of an African postcolonial spirituality - of a spiritual life and a description of divinity which, on the one hand, is free from the trappings of neo-colonialism and reflects what the West likes to regard as a homogenous African identity but which, on the other hand, embodies the values of freedom and equality which postcolonial intellectuals treasure. For some thinkers, such a postcolonial spirituality would entail a neo-traditionalist return to indigenous polytheism; for others, it requires conversion to Islam or a refashioning of Christianity along Africanist lines. For Okri and for some other contemporary black writers such as Alice Walker and Toni Morrison (see Dieke; Ryan; Smith), the answer is New Ageism, the de-traditionalized eclectic fashioning of a spiritual "path" individually suited to one's own Self-realization - a kind of spirituality capable of absorbing whatever religious traditions happen to resonate with the practitioner's identity. If Okri's case is anything to go by, then literary and non-literary representations of postcolonial spirituality must remain content to be impure, internally shadowed by the very forms of worship and theology they push away from and contest. 


\section{Works Cited}

Adu-Gyamfi, Yaw. “Wole Soyinka’s 'Dawn’ and the Cults of Ogun.” ARIEL 28.4 (1997): 73-89.

Aworeni. Personal interview. Ile-Ife. 27 Apr. 1999.

Babalola, E. O. "Traditional Therapeutics and its Application to the Abiku Phenomenon in Owo Yoruba Community." Africana Marburgensia suppl. 16 (1996): 60-9.

Bannister, Robert C. Social Darwinism: Science and Myth in Anglo-American Thought. Philadelphia: Temple UP, 1979.

BEISER, Fredrick C. The Sovereignty of Reason: The Defense of Rationality in Early English Enligbtenment. Princeton, NJ: Princeton UP, 1996.

Crowther, Samuel A[djai]. A Vocabulary of the Yoruba Language. London: CMS, 1852.

Dieke, Ikenna. "From Fractured Ego to Transcendent Self: A Reading of Alice Walker's Possessing the Secret of Joy." Literary Griot 11.1 (1999): 48-68.

EluIs, A[lfred] B[urdon]. The Yoruba-Speaking Peoples of the Slave Coast of West Africa. London: Oxford UP, 1894.

Farrow, Stephen Septimus. Faith, Fancies and Fetish; or, Yoruba Paganism. New York: Macmillan, 1926.

Hammer, Olav. Claiming Knowledge: Strategies of Epistemology from Theosophy to the New Age. Leiden: Brill, 2001.

IfaYINKA, Isola Odutolu. Personal interview. Abeokuta. 25 May 1999.

JoneS, Greta. Social Darwinism and English Thought: The Interaction Between Biological and Social Theory. Brighton: Harvester, 1980.

Kokumo. Dir. Akeem Olumegbon. Lagos: Olumegbon Films, n.d. [c. 1998].

LuCAS, J. Olumide. The Religion of the Yorubas. Lagos: CMS Bookshop, 1948.

McCABE, Douglas. "Histories of Errancy: Oral Yoruba Abiku Texts and Soyinka's 'Abiku." Research in African Literatures 33.1 (2002): 45-74.

—. "'Higher Realities': New Spirituality in Ben Okri's The Famished Road." Research in African Literatures 36.4 (2005): 1-21.

Morton-Williams, Peter. "The Atinga Cult Among the South-Western Yoruba: A Sociological Analysis of a Witch-Finding Movement." Bulletin de l'IFAN ser. B 18.3-4 (1956): 315-34.

Nisbet, Robert. History of the Idea of Progress. London: Heinemann, 1980.

Numbers, Ronald, and John Stenhouse, eds. Disseminating Darwin: The Role of Place, Race, Religion, and Gender. Cambridge: Cambridge UP, 1999.

Okri, Ben. The Famished Road. London: Jonathan Cape, 1991.

-. Infinite Riches. London: Phoenix, 1998.

Paxton, Nancy L. George Eliot and Herbert Spencer: Feminism, Evolutionism, and the Reconstruction of Gender. Princeton, NJ: Princeton UP, 1991.

Prince, Raymond. “The Yoruba Image of the Witch.” Journal of Mental Science 107 (1965): 795-805.

QuAYson, Ato. Strategic Transformations in Nigerian Writing: Orality and History in the Work of Rev. Samuel Johnson, Amos Tutuola, Wole Soyinka, and Ben Okri. Bloomington and Indianapolis: Indiana UP, 1997.

RYAN, Judylyn S. "Spirituality and/as Ideology in Black Women's Literature: The Preaching of Maria W. Stewart and Baby Suggs, Holy." Women Preachers and Prophets Through Two Millennia of Christianity. Ed. Beverly Mayne Kienzle and Pamela J. Walker. Berkeley, CA: U of California P, 1998.

SHAw, Rosalind. "The Production of Witchcraft/Witchcraft as Production: Memory, Modernity, and the Slave Trade in Sierra Leone." American Ethnologist 24.4 (1997): 856-76.

Smith, Pamela. "Green Lap, Brown Embrace, Blue Body: The Ecospirituality of Alice Walker." Cross Currents 48.4 (1998-99): 471-87.

SOYINKA, Wole. The Road. London: Oxford UP, 1965.

—. "Death in the Dawn." Idanre and Other Poems. London: Methuen, 1967. 11.

TaLBot, Percy Amaury. The Peoples of Southern Nigeria. 4 vols. London: Oxford UP, 1926. 